UDC 811.111'42:316.647.5

DOI https://doi.org/10.32841/2409-1154.2020.44.28

\author{
Radzievska O. V., \\ Candidate of Pedagogical Sciences, \\ Associate Professor at the Department of Foreign Languages \\ Donbass State Pedagogical University
}

\title{
THE LEXICAL AND SEMANTIC PROBLEMS OF TRANSLATION AND THE WAYS OF THEIR SOLVING
}

Summary. The article analyzes the main features and problems of translating lexical units from a foreign language. The author emphasizes the importance of this process and points out the difficulties that may arise during translation. It is separately noted that the personality of the translator must be comprehensively developed and have a high overall intelligence. The basic approaches to text translation are considered: cognitive, global and special approaches. The author also defines the main task of translation - the transfer of the basic idea and meaning from one language to another, while preserving all the linguistic and cultural features of the text. Translators - like all professionals, must undergo continuous training and refinement of their skills through experience, selfexamination and self-correction. Their "production" potential should not always be measured in terms of translated pages or words, but rather, to evaluate the quality of the finished work, which requires a set of standards and rules. The main task of translation is to transfer the basic idea and meaning from a foreign language to the native language, taking into account all linguistic and cultural features.

Finding dilemmas is an ongoing process in translator work. This includes dealing with such problematic phenomena as: linguistic or cultural "non-translation", the ability to manage the disadvantages and benefits of translation, the solution of lexical ambiguity, and so on. These problems are solved through the use of various mechanisms, such as explanatory notes, adaptation, equivalence, paraphrase, analogy, etc.

Translators should also understand that the meaning of what is said is not just words. Therefore, adequate decoding and re-encoding of figures, tables and diagrams; standardized terms, acronyms, metonymy, place names, etc. are elements that should be given particular attention. A professional translator should identify some significant anchor points to maximize the approximation of the text to be translated, for example: the purpose of the text, its readership, the specific standards used by the author, the message that carries the text, the type of discourse, the translator, and the reader.

Key words: translation, transformation, efficiency, mother tongue, culture.

Formulation of the problem. Translation activities have several specific goals, depending on the specific situation and field of activity. The main purpose of translation is to serve as an intercultural multilingual means of communication between peoples. In the last few decades, this activity has evolved in the context of increased international trade, increased migration, globalization, recognition of linguistic minorities and the expansion of the media. In this regard, the translator plays an important role as a multilingual transmitter of culture and information, who tries to interpret the concepts and content of different statements as accurately as possible.
The relevance of the study is undeniable. The consequences of incorrect translations can be catastrophic, especially if done by non-professionals, and mistakes made in the performance of these activities can be fatal. This is especially true in cases of serious misconduct in the fields of medicine, legal matters or technology.

It is quite obvious that poor translation can not only lead to minor confusion, but can also be a matter of life and death. Therefore, the purpose of translator training lies not only in the acquisition of orientation skills in languages, translation and its technologies, but also in specific areas of knowledge and, equally importantly, in professional ethics.

The subject of the study is the problem of translation from a foreign language into a native language.

The object of the research is the process of translation of lexical units from foreign into their native language.

The purpose of the study is to analyze the features of the translation process, its problems and ways of solving them.

Analysis of research and publications. Many domestic and foreign scholars have considered the laws, principles, and problems of the translation process, including: V. Karaban, J. Retzker, V. Komissar, P. Newmark, R. Bell, and others.

Most translation practice theorists agree that translation is understood as a process of transmitting information from a foreign language into their native language. However, market demands are increasingly demanding that translators translate texts into a language that is not their native language. P. Newmark calls this phenomenon "service translation". The scientist also stated: "I assume that most translators learn to translate into their usual language of use, as this is the only way they can translate naturally, accurately, and with maximum efficiency. Thus, most translators make translations based on their native language" [3, p. 25].

This fact makes the translation process more difficult, sometimes leading to mediocre translations, which no doubt have to be reviewed and edited before being published.

Main material. If translation is a discursive operation between language and thought, we must recognize that in the art or skill of translation, we will inevitably face many obstacles.

D. Delisle emphasizes how thin the translation process is: "Translation is hard work that, from time to time, leads you to despair, but at the same time it constantly enriches us with new skills and knowledge" [1, p. 101].

There are many obstacles that can arise during the translation process, regardless of the nature of the text we are working with. The first problem is related to the ability to read and understand the original language. Once the interpreter has dealt with this obstacle, further translation difficulties will have a semantic and cultural character [5]. 
Very often we come across such a phenomenon as "linguistic non-translation", which includes related and similar words, tracing books and its forms, standardized terms, neologisms, aphorisms, etc.

Another obstacle for the translator is the "cultural impossibility of translation", which includes idioms, sayings, sayings, jokes, puns, etc. Care should be taken with regard to such words or expressions in order to avoid incorrectness and abuse of language [2].

Similarly, we often come across special terms for which even a dictionary or native speaker cannot provide a solution for conveying the exact meaning. In such cases, it should be noted that one of the best qualities of a translator is "contextualizing intuition", that is, the ability to quickly find the closest interpretation of the meaning of an unknown element in its context.

Whatever the difficulties during the translation process, it should be focused on the essence of the message and the fidelity to the value of the source text transmitted in the language of the translation. According to E. Nida and C. Taber: "Translation consists of reproducing the closest equivalent of the message from the source to the language of translation with all the semantic and stylistic aspects" $[4$, p. 68].

To a large extent, the quality of the translation will depend on the personal qualities of the translator himself, that is, on his knowledge, skills, level of study, cultural background, experience and even mood. M. Newmark highlights some of the essential characteristics that any professional translator should have: the ability to recognize texts in a foreign language, knowledge and sensitivity to the language (both native and foreign), competence in oral and written language [3].

In addition, M. Trikas refers to intuition or common sense as the most important of all the qualities of a translator. In other words, in the process of translation it is very important to use a combination of intelligence, sensitivity and intuition: "The translation process is a complex mechanism of choice of approaches in which all intellectual abilities, skills and intuition must be used" [5, p. 98].

There are several approaches to improving translation skills:

1. The cognitive approach is applied to the process of transferring ideas from one language to another, which obviously means much more than a simple model of reproduction. In the preparatory phase of translation, cognition in the form of selfawareness and self-confidence plays a very important role, since this period involves conscious mental activity in which problems with translation are identified and analyzed [2].

It should be noted that, from a psychological and social point of view, an interpreter who is an employee of an intellectual field with special professional characteristics will be more successful if special attention is paid to his socio-affective development. In this case, he or she may be better prepared to work with people, and to achieve a higher level of tolerance, exhibiting self-criticism and sensitivity.

2. Global approach. Considering the basic approaches to translation, it should be noted that the most famous translation theorists agree on the following aspects:

First, there are certain rules for understanding and interpreting texts, which mean managing the principles of special approaches to different types of texts, taking into account their individual characteristics. This competence includes reading comprehension and interpreting messages (encoding and decoding).

Secondly, reformulation is also an important aspect. This means applying different strategies to the process of message restitution (recoding), by selecting the appropriate methods and techniques. The most commonly used techniques for conveying the main idea contained in the translation units that a translator can use are: transferring the cultural or functional equivalent, synonymy, transposition, modulation; reducing and expanding the meaning of a word, as well as enhancing its meaning [3].

These elements form the essence of translation and are part of the translator's competence. They should be most clearly marked when preparing future translators. Different types of literature should also be used for these purposes: concurrent texts, monolingual and bilingual dictionaries, encyclopedias, terminology databases, and other sources.

Third, translation theorists attach great importance to the evaluation of the result, that is, to prove the meaning of the translated text and its original. In this case, the translator has the ability to adequately evaluate the translation, mark its shortcomings, demonstrating the ability to selfcorrect. Viewing the result of a failed translation will always lead to a higher quality final translation.

3. Special approaches. Most translation theorists believe that specific approaches to text translation are generally similar. On the one hand, one or more translation approaches or models must be used. On the other hand, there is always a way to approach the text of the target language, regardless of whether the translator chooses certain types of models: author-oriented, structurallyoriented, text-oriented, cognitive or reader-oriented. Depending on the situation, translators will use a particular model, but many are prone to eclectic integration of all models.

Translators should understand that misinterpretation of the text significantly reduces the quality of the translation. Therefore, reading comprehension strategies for translation (word selection, translation difficulty, contextualization of lexical elements, adaptation, analysis, etc.) should be used.

Finding dilemmas is an ongoing process in translator work. This includes dealing with such problematic phenomena as: linguistic or cultural "non-translation", the ability to manage the disadvantages and benefits of translation, the solution of lexical ambiguity, and so on. These problems are solved through the use of various mechanisms, such as explanatory notes, adaptation, equivalence, paraphrase, analogy, etc.

Translators should also understand that the meaning of what is said is not just words. Therefore, adequate decoding and re-encoding of figures, tables and diagrams; standardized terms, acronyms, metonymy, place names, etc. are elements that should be given particular attention.

A professional translator should identify some significant anchor points to maximize the approximation of the text to be translated, for example: the purpose of the text, its readership, the specific standards used by the author, the message that carries the text, the type of discourse, the translator, and the reader.

Another important aspect is pre-editing the source text to identify possible inaccuracies on the one hand, and post-editing the translated text to test the use of the most appropriate syntactic, semantic units, on the other.

Among the formal questions, translators must know and control the sound effect and cadence of the translated text to avoid incorrect phonetic combinations and tracing in the original language.

It should also be noted that translators must constantly make the choice of a translation strategy in each paragraph to decide which ones are most useful for correctly communicating the ideas of a particular text. This means adapting the most effective strategies and methods to the requirements of the text, rather than applying only one specific technique to all types of text. 
Another important aspect is that translators should always retain the style, essence, meaning of the source text, as well as its format: paragraphs, indentations of the table, references to sources. By adhering to all these forms, we will maximize the approximation of the original text.

Conclusion. Translators - like all professionals, must undergo continuous training and refinement of their skills through experience, self-examination and self-correction. Their "production" potential should not always be measured in terms of translated pages or words, but rather, to evaluate the quality of the finished work, which requires a set of standards and rules. The main task of translation is to transfer the basic idea and meaning from a foreign language to the native language, taking into account all linguistic and cultural features.

To solve translation problems, the translator must use all his or her mind, creativity, intuition, and ingenuity. In this matter, the overall level of the translator's intelligence and his / her professional training is very important. An analysis of translation problems with certain linguistic units may be a prospect for further research.

\section{References:}

1. Delisle J. L'Enseignement de l'interprétation et de la traduction. Ottawa : Editions de l'Université d'Ottawa, 1981. 321 p

2. Kussmaul P. Training the Translator. L. : John Benjamins Publishing Co, 1995. 145 p.

3. Newmark P. A Textbook of Translation. C. : Library of Congress Cataloging-in-Publication Data, 1995. $457 \mathrm{p}$.

4. Nida E. The Theory and Practice of Translating. N.Y. : Brill, Leiden, $1974.195 \mathrm{p}$.

5. Tricás M. Manual de traducción francés-castellano. B. : Gedisa S.A, 1995. $430 \mathrm{p}$.

Радзієвська О. В. Лексичні та семантичні проблеми процесу перекладу та шляхи їх вирішення

Анотація. У статті аналізуються основні особливості та проблеми перекладу лексичних одиниць 3 іноземної мови. Автор підкреслює важливість цього процесу, а також вказує на труднощі, які можуть виникнути під час перекладу. Окремо відзначено, що особистість перекладача повинна бути всебічно розвинена і мати високий загальний інтелект. Розглянуто основні підходи до перекладу текстів: когнітивний, глобальний та спеціальні підходи. Автор також визначає основну задачу перекладу - передача основної ідеї та сенсу з однієї мови на іншу, при цьому зберігаючи всі лінгвістичні та культурні особливості тексту. Перекладачі, як і всі професіонали, повинні проходити постійне навчання та вдосконалення своїх навичок шляхом набуття досвіду, самоаналізу і самокорекції. Їхній «виробничий» потенціал не завжди слід вимірювати з точки зору переведених сторінок або слів, а скоріше оцінювати якість готової роботи, яка вимагає дотримання безлічі стандартів і правил. Головне завдання перекладу - це передача основної ідеї і сенсу з іноземної мови на рідну, при цьому враховуючи всі лінгвістичні та культурні особливості

Пошук рішень дилем є постійним процесом у роботі перекладача. Це включає в себе роботу з такими проблемними явищами, як: лінгвістична або культурна «нетрансльованість», здатність управління недоліками і перевагами перекладу, рішення лексичної двозначності і ін. Ці проблеми вирішуються шляхом використання різних механізмів: пояснювальних приміток, адаптації, еквівалентності, перефразування, аналогії і т.п.

Перекладачі також повинні розуміти, що сенс сказаного передається не тільки словами. Отже, адекватне декодування і повторне кодування малюнків, таблиць та діаграм; стандартизовані терміни, акроніми, метонімія, топоніми і т. п. - це елементи, яким має бути приділена особлива увага. Професійний перекладач повинен визначити деякі суттєві опорні точки для максимального наближення до тексту, які потрібно перекласти, наприклад: мета тексту, його читацька аудиторія, особливі стандарти, використовувані автором, послання, яке несе в собі текст, вид дискурсу, перекладача і читача.

Ключові слова: переклад, трансформація, ефективність, рідна мова, культура. 